\title{
Synthesis and $\mathrm{H}^{+}, \mathrm{Cu}^{2+}$, and $\mathrm{Zn}^{2+}$ Coordination Behavior of a Bis(fluorophoric) Bibrachial Lariat Aza-Crown
}

\author{
M. Paz Clares, ${ }^{\dagger}$ Juan Aguilar, ${ }^{\ddagger}$ Ricardo Aucejo, ${ }^{\dagger}$ Carlos Lodeiro,, M. Teresa Albelda, ${ }^{\dagger}$

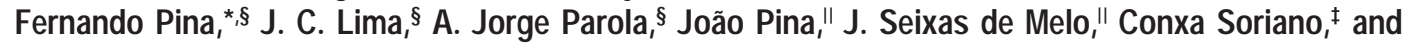 \\ Enrique García-España*,t \\ Departament de Química Inorgànica ICMOL, Facultat de Química, Universitat de València, \\ Burjassot, Spain, Departamento de Química, REQUIMTE-CQFB, Faculdade de Ciências e \\ Tecnologia, Universidade Nova de Lisboa, Portugal, Departamento de Química ICMOL, \\ Universidade de Coimbra, 3004-535 Coimbra, Portugal, and Departament de Química Orgànica, \\ Facultat Farmàcia, Universitat de València, Burjassot, Spain
}

Received March 9, 2004

The synthesis, protonation behavior, and $\mathrm{Cu}^{2+}$ and $\mathrm{Zn}^{2+}$ coordination chemistry of the novel bibrachial aza lariat ether (naphthalen-1-ylmethyl)[2-(20-\{2-[(naphthalen-1-ylmethyl)amino]ethyl\}-3,6,9,17,20,23,29,30-octaazatricyclo[23.3.1.1*11,15*]triaconta-1(29),11(30),12,14,25,27-hexaen-6-yl)ethyl]amine (L) are discussed. The macrocycle, which has two aminoethyl naphthyl moieties symmetrically appended to a 2:2 azapyridinophane structure, displays, in the $\mathrm{pH}$ range 2-11, six protonation steps that correspond to the protonation of the secondary amino groups. Steadystate fluorescence measurements show emissions due to the monomer and to the excimer formed between the two naphthalene fragments of the macrocycle. The time-resolved fluorescence data, obtained by the time-correlated single photon counting technique, show that a significant percentage of excimer is preformed as ground-state dimers. The ligand $\mathbf{L}$ forms with the metal ions $\mathrm{Cu}^{2+}$ and $\mathrm{Zn}^{2+}$ mono- and dinuclear complexes in aqueous solution. The influence of metal coordination in the fluorescence emission of $L$ is analyzed. The acid-base, coordination capabilities, and emissive behavior of $L$ are compared with those presented by its synthetic precursor $\mathbf{L} 1$, which has a tripodal tris(2-aminoethyl)amine structure functionalized at one of its terminal amino groups with a naphthyl moiety.

\section{Introduction}

To achieve selective binding of a given guest species and couple the recognition event with a change in a physical property able to signal the process, multifunctional receptors need to be designed and built. ${ }^{1}$ Lariat ethers constitute a classical category of receptors in which a macrocyclic structure is covalently linked to appendages containing additional donor atoms. Most lariat ethers are based on crown-ether or oxa-azacrown macrocycles and are designed to complex ammonium cations or spherical metal ions. ${ }^{2}$

\footnotetext{
* Authors to whom correspondence should be addressed. E-mail: enrique.garcia-es@uv.es (E.G.-E.); fjp@dq.fct.unl.pt (F.P.). Fax: 963544322 (E.G.-E.); 212948550 (F.P.). Tel: 963544879 (E.G.-E.); 212948355 (F.P.)

Facultat de Química, Universitat de València.

F Facultat Farmàcia, Universitat de València.

$\S$ Universidade Nova de Lisboa.

" Universidade de Coimbra.

(1) (a) Lehn, J. M. Angew. Chem., Int. Ed. Engl. 1988, 27, 89. (b) Lehn, J. M. Supramolecular Chemistry. Concepts and Perspectives; VCH: Weinheim, Germany, 1995.
}

6114 Inorganic Chemistry, Vol. 43, No. 19, 2004
These compounds were born with the idea of joining high thermodynamic stability with fast kinetics to facilitate transport processes through organic membranes. The coordination of the donor atoms in the dangling arms to the metal ion will provide three-dimensionality to the structure preserving at the same time fast coordination dynamics.

To bind transition metal ions, softer atoms should replace the hard ethereal oxygen donors. Nitrogen atoms are appropriate donors for binding divalent first transition metal ions, and new categories of lariat compounds are based on all aza macrocyclic structures. ${ }^{3}$ Aza macrocycles are, on the other hand, ambivalent receptors since they can coordinate metal ions or anions by simply changing the $\mathrm{pH}$ of the medium. If the number of available nitrogen donors is large

(2) (a) Gokel, G. W. Chem. Soc. Rev. 1992, 21, 32. (b) Gokel, G. W. Barbour, L. J.; De Wall, S. L.; Meadows, E. S. Coord. Chem. Rev. 2001, 222, 127.

(3) Hartley, J. H.; James, T. D.; Ward, C. J. J. Chem. Soc., Perkin Trans. $12000,3155$.

10.1021/ic049694t CCC: $\$ 27.50$ C 2004 American Chemical Society Published on Web 08/25/2004 
enough they will coordinate metal ions, while if the number and disposition of protonated ammonium sites is adequate, they will be able to coordinate anionic species. ${ }^{4}$ Additionally, if the receptor disposes of subunits displaying physical properties whose magnitudes are largely affected by the interaction with the guest, then the receptor can operate as a molecular sensor. ${ }^{5}$ Polyamine receptors have also constituted the chemical basis of elementary systems, capable of performing simple movements controlled by external inputs $\left(\mathrm{pH}\right.$, temperature, light, redox potential, metal ions). ${ }^{6,7}$

Following these ideas, here we report on the receptor $\mathbf{L}$ in which two aminoethyl naphthyl moieties have been symmetrically appended to a 2:2 azapyridinophane structure (see Chart 1).

This multifunctional receptor meets the characteristics of both the cyclophane and the bibrachial lariat ether receptors. ${ }^{8}$ The nitrogen donors of the macrocycle can be, at least, classified into three categories, secondary and tertiary nitrogens in the bridges and sidearms and the softer pyridine nitrogen donors. The naphthalene rings can contribute to the binding via $\pi$-cation interactions and help to signal the encapsulation of a given metal by changing its luminescent behavior. The movements of the pendant sidearms can, on the other hand, give rise to particular emissive properties. ${ }^{9}$

In this first paper concerning the chemistry of $\mathbf{L}$, we report on its synthesis and present an overview of its capacity to interact with metal ions. To do so, we have studied the interaction in water of $\mathbf{L}$ with the divalent metal ions $\mathrm{Cu}^{2+}$ and $\mathrm{Zn}^{2+}$. We also report on the fluorescent behavior of the receptor $\mathbf{L}$ alone and in the presence of the metal ions $\mathrm{Cu}^{2+}$ and $\mathrm{Zn}^{2+}$. The acid-base, coordination, and emissive

(4) (a) Dietrich, B. Pure Appl. Chem. 1993, 65, 1457. (b) Bianchi, A.; Bowman-James, K.; García-España, E. Supramolecular Chemistry of Anions; Wiley-VCH: New York, 1997. (c) Beer, P. D.; Gale, P. A Angew. Chem., Int. Ed. 2001, 40, 486. (d) Gale, P. A. Coord. Chem. Rev. 2001, 213, 79. (e) Ilioudis, C. A.; Steed, J. W. J. Supramol. Chem. 2001, 1,165 .

(5) (a) Czarnik, A. W. Fluorescent Chemosensors for Ion and Molecule Recognition; American Chemical Society: Washington, DC, 1993. (b) Bissel, R. A.; de Silva, A. P.; Gunaratne, H. Q. N.; Lynch, P. L. M.; Maguire, G. E. M.; Sandanayake, K. R. A. S. Chem. Soc. Rev. 1992, 187. (c) de Silva, A. P.; Gunaratne, H. Q.; Gunnlaugsson T.; Huxley, A. J. M.; McCoy, C. P.; Rademacher, J. T.; Rice, T. E. Chem. Rev. 1997, 97, 1515. (d) de Silva, A. P.; Fox, D. B.; Moody, T. S.; Weir, S. M. Pure Appl. Chem. 2001, 73, 503. (e) de Silva, A. P.; Fox, D. B.; Moody, T. S.; Weir, S. M. Trends Biotechnol. 2001, 19, 29. (f) de Silva, A. P.; Fox, D. B.; Huxley, A. J. M.; McClenaghan, N. D.; Roiron, J. Coord. Chem. Rev. 1999, 186, 297. (g) Kimura, E.; Koike, T. Chem. Soc. Rev. 1998, 27, 179.

(6) (a) Kimura, E.; Koike, T. J. Chem. Soc., Chem. Commun. 1998, 1495. (b) König, B.; Pelka, M.; Zieg, H.; Ritter, T.; Bouas-Laurent, H.; Bonneau, R.; Desvergne, J. P. J. Am. Chem. Soc. 1999, 121, 1681. (c) McLaren, F.; Moore, P.; Wynn, A. M. J. Chem. Soc., Chem. Commun. 1989, 798. (d) Fabbrizzi, L.; Licchelli, M.; Rabaioli, G.; Taglietti, A. Coord. Chem. Rev. 2000, 205, 85.

(7) (a) Bernardo, M. A.; Alves, S.; Pina, F.; Seixas de Melo, J.; Albelda, M. T.; García-España, E.; Llinares, J. M.; Soriano, C.; Luis, S. V. Supramol. Chem. 2001, 13, 435. (b) Albelda, M. T.; Bernardo, M. A.; Díaz, P.; García-España, E.; Seixas de Melo, J.; Pina, F.; Soriano, C.; Luis, S. V. Chem. Commun. 2001, 1520.

(8) Gatto, V. J.; Arnold, K. A.; Viscariello, A. M.; Miller, S. R.; Gokel, G. W. Tetrahedron Lett. 1986, 27, 327.

(9) (a) Bencini, A.; Bianchi, A.; Lodeiro, C.; Masotti, A.; Parola, A. J.; Pina, F.; Seixas de Melo, J.; Valtancoli, B. Chem. Commun. 2000, 1639. (b) Amendola, V.; Fabbrizzi, L.; Mangano, C.; Pallavicini, P. Struct. Bonding 2001, 99, 79. (c) Parker, D.; Williams, J. A. G. J. Chem. Soc., Perkin Trans. 2 1995, 1305. (d) Beeby, A.; Parker, D.; Williams, J. A. G. J. Chem. Soc., Perkin Trans. 2 1996, 1565.

\section{Chart 1}
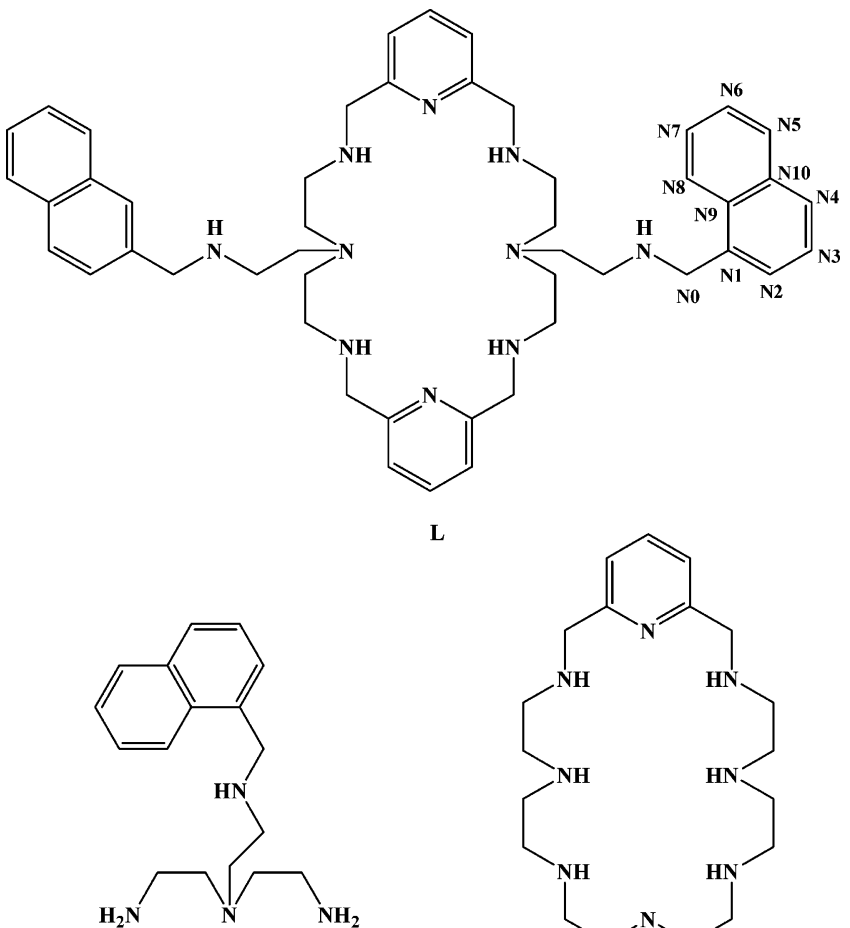

L

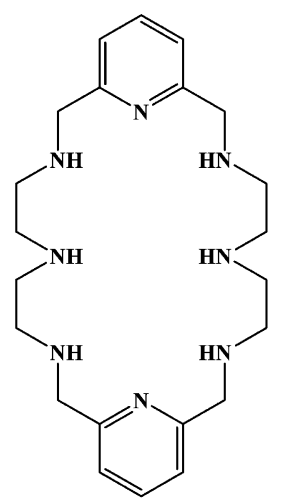

L2

behavior of $\mathbf{L}$ is compared with that presented by its synthetic precursor L1 (see Chart 1), which has a tripodal tris(2aminoethyl)amine structure functionalized at one of its terminal amino groups with a naphthyl moiety.

\section{Experimental Section}

Synthesis of L. Synthesis of L1. Naphthalene-1-carbaldehyde $(1.00 \mathrm{~g}, 6.4 \mathrm{mmol})$ and $N^{1}, N^{1}$-bis(2-aminoethyl)ethane-1,2-diamine $(2.80 \mathrm{~g}, 19.2 \mathrm{mmol})$ were dissolved in $100 \mathrm{~mL}$ of $\mathrm{EtOH}-\mathrm{CH}_{3} \mathrm{CN}$ $(1: 1)$. The resulting solution was stirred for $2 \mathrm{~h}$ and then the solvent evaporated. The obtained residue was dissolved in $\mathrm{EtOH}$, and $\mathrm{NaBH}_{4}(2.24 \mathrm{~g}, 59.0 \mathrm{mmol})$ was added portionwise. After $2 \mathrm{~h}$ at room temperature the solvent was evaporated to dryness. The resulting residue was treated with water and repeatedly extracted with dichloromethane $(3 \times 50 \mathrm{~mL})$. The organic phase was then dried with anhydrous sodium sulfate and the solvent evaporated to yield the free amine as a yellowish oil. The oil was then taken in a minimum amount of EtOH and precipitated with aqueous $\mathrm{HCl}$ as its hydrochloride salt $(2.4 \mathrm{~g}, 93 \%)$. Mp: $203-205{ }^{\circ} \mathrm{C} .{ }^{1} \mathrm{H}$ NMR: $2.85(\mathrm{t}, 4 \mathrm{H}, J=6 \mathrm{~Hz}), 2.93(\mathrm{t}, 2 \mathrm{H}, J=7 \mathrm{~Hz}), 3.09(\mathrm{t}, 4 \mathrm{H}$, $J=6 \mathrm{~Hz}), 3.32(\mathrm{t}, 2 \mathrm{H}, J=7 \mathrm{~Hz}), 4.82(\mathrm{~s}, 2 \mathrm{H}), 7.59-7.76(\mathrm{~m}$, 4H), 8.06-8.16 ppm (m, 3H). ${ }^{13} \mathrm{C}$ NMR: $36.7,44.3,48.5,48.8$, 50.1, 122.9, 126.0, 127.1, 127.9, 129.5, 130.1, 131.0, 131.3 ppm. Anal. Calcd for $\mathrm{C}_{17} \mathrm{H}_{29} \mathrm{~N}_{4} \mathrm{Cl}_{3}$ : C, 51.6, $\mathrm{H}, 7.3, \mathrm{~N}, 14.1$. Found: C, 51.8, H, 7.5, N, 13.9.

Synthesis of (Naphthalen-1-ylmethyl)[2-(20-\{2-[(naphthalen1-ylmethyl)amino]ethyl $\}-3,6,9,17,20,23,29,30$-octaazatricyclo[23.3.1.1*11,15*]triaconta-1(29), 11(30),12,14,25,27-hexaen-6yl)ethyl]amine (L). 2,6-Pyridine-dicarbaldehyde ( $0.80 \mathrm{~g}, 5.9 \mathrm{mmol})$ dissolved in $100 \mathrm{~mL}$ was dropwise added to a solution of $\mathrm{L}^{1}(1.7$ g, $5.96 \mathrm{mmol})$ in EtOH and stirred for $2 \mathrm{~h}$. Solid $\mathrm{NaBH}_{4}(1.80 \mathrm{~g}$, $47.4 \mathrm{mmol}$ ) was then added portionwise. After $2 \mathrm{~h}$ the solvent was 
evaporated to dryness. The residue was treated with water and repeatedly extracted with $\mathrm{CH}_{2} \mathrm{Cl}_{2}(3 \times 40 \mathrm{~mL})$. The organic phase was dried with anhydrous sodium sulfate and the solvent evaporated to dryness to yield an oil (3.3 g, $2.4 \mathrm{mmol}, 40 \%)$. The oil was then taken in a minimum amount of $\mathrm{EtOH}$ and precipitated with aqueous $\mathrm{HClO}_{4}$ as its perchlorate salt $(1.84 \mathrm{~g}, 31 \%)$. Mp: $195-200{ }^{\circ} \mathrm{C} .{ }^{1} \mathrm{H}$ NMR: $2.73-2.73(\mathrm{~m}, 2 \mathrm{H}), 3.00(\mathrm{t}, 2 \mathrm{H}, J=6 \mathrm{~Hz}), 3.08$ (t, 2H, $J$ $=7 \mathrm{~Hz}), 4.15(\mathrm{~s}, 4 \mathrm{H}), 4.58(\mathrm{~s}, 2 \mathrm{H}), 7.44(\mathrm{~d}, 2 \mathrm{H}, J=8 \mathrm{~Hz}), 7.54$ $(\mathrm{t}, 1 \mathrm{H}, J=8 \mathrm{~Hz}), 7.59(\mathrm{t}, 1 \mathrm{H}, J=8 \mathrm{~Hz}), 7.66(\mathrm{t}, 1 \mathrm{H}, J=8 \mathrm{~Hz})$, $7.66(\mathrm{~d}, 1 \mathrm{H}, J=8 \mathrm{~Hz}), 7.91(\mathrm{t}, 1 \mathrm{H}, J=8 \mathrm{~Hz}), 7.93(\mathrm{t}, 1 \mathrm{H}, J=8$ $\mathrm{Hz}), 7.97(\mathrm{~d}, 1 \mathrm{H}, J=8 \mathrm{~Hz}), 8.07 \mathrm{ppm}(\mathrm{d}, 1 \mathrm{H}, J=8 \mathrm{~Hz}) \cdot{ }^{13} \mathrm{C}$ NMR: $43.5,44.8,47.8,48.1,49.3,50.9,122.8,123.3,125.8,126.3$, 126.9, 127.7, 129.3, 130.0, 130.8, 131.1, 133.7, 139.6, $150.5 \mathrm{ppm}$. MS $(\mathrm{m} / z ; \mathrm{FAB})$ : 779, $[\mathrm{M}+\mathrm{H}]^{+}$. Anal. Calcd for $\mathrm{C}_{48} \mathrm{H}_{68} \mathrm{~N}_{10^{-}}$ $\mathrm{Cl}_{6} \mathrm{O}_{24}:$ C, 38.9, H, 4.9, N, 9.8. Found: C, 39.1, H, 4.9, N, 9.5.

Emf Measurements. The potentiometric titrations were carried out at $298.1 \pm 0.1 \mathrm{~K}$ using $0.15 \mathrm{M} \mathrm{NaCl}$ as supporting electrolyte. The experimental procedure (buret, potentiometer, cell, stirrer, microcomputer, etc.) has been fully described elsewhere. ${ }^{10}$ The acquisition of the emf data was performed with the computer program PASAT. ${ }^{11}$ The reference electrode was an $\mathrm{Ag} / \mathrm{AgCl}$ electrode in saturated $\mathrm{KCl}$ solution. The glass electrode was calibrated as a hydrogen-ion concentration probe by titration of previously standardized amounts of $\mathrm{HCl}$ with $\mathrm{CO}_{2}$-free $\mathrm{NaOH}$ solutions and the equivalent point determined by Gran's method, ${ }^{12}$ which gives the standard potential, $E^{\circ}$, and the ionic product of water $\left(\mathrm{p} K_{\mathrm{w}}=13.73(1)\right)$.

The computer program HYPERQUAD was used to calculate the protonation and stability constants..$^{13}$ The $\mathrm{pH}$ range investigated was $2.0-11.0$, and the concentration of the metal ions and of the ligands ranged from $1 \times 10^{-3}$ to $5 \times 10^{-3} \mathrm{M}$ with $\mathrm{M}: \mathrm{L}$ molar ratios varying from 2:1 to 1:2. The different titration curves for each system (at least two) were treated either as a single set or as separated curves without significant variations in the values of the stability constants. Finally, the sets of data were merged together and treated simultaneously to give the final stability constants.

NMR Measurements. The ${ }^{1} \mathrm{H}$ and ${ }^{13} \mathrm{C}$ NMR spectra were recorded on a Varian UNITY 300 spectrometer operating at 299.95 $\mathrm{MHz}$ for ${ }^{1} \mathrm{H}$ and at 75.43 for ${ }^{13} \mathrm{C}$. For the ${ }^{13} \mathrm{C}$ NMR spectra, dioxane was used as a reference standard $(\delta=67.4 \mathrm{ppm})$, and for the ${ }^{1} \mathrm{H}$ spectra, the solvent signal was used.

ROESY (rotating frame spectroscopy) was recorded at three different mixing times, 100, 150, and $600 \mathrm{~ms}(\mathrm{pH}=4, T=298$ $\mathrm{K}$ ) on a Bruker Avance DPX $500 \mathrm{MHz}$ operating at $500.130 \mathrm{MHz}$. Adjustments to the desired $\mathrm{pH}$ were made using drops of $\mathrm{DCl}$ or $\mathrm{NaOD}$ solutions. The $\mathrm{pD}$ was calculated from the measured $\mathrm{pH}$ values using the correlation $\mathrm{pH}=\mathrm{pD}-0.4 .{ }^{14}$

Diffusion ordered spectroscopy (DOSY) ${ }^{15}$ experiments were performed using the bipolar pulse longitudinal eddy current delay (BPPLED) sequence.

Spectrophotometric and Spectrofluorimetric Titrations. Absorption spectra were recorded on a Shimadzu UV-2501PC spectrophotometer, and fluorescence emissions, on a Horiba-Jobin-Yvon

(10) García-España, E.; Ballester, M. J.; Lloret, F.; Moratal, J. M.; Faus, J.; Bianchi, A. J. Chem. Soc., Dalton Trans. 1988, 1, 101.

(11) Fontanelli, M.; Micheloni, M. Proceedings of the 1st Spanish-Italian Congress on Thermodynamics of Metal Complexes; Diputación de Castellón: Castellón, Spain, 1990.

(12) (a) Gran, G. Analyst 1952, 77, 881. (b) Rossotti, F. J.; Rossotti, H. J. Chem. Educ. 1965, 42, 375.

(13) (a) Sabatini, A.; Vacca, A.; Gans, P. Coord. Chem. Rev. 1992, 120 , 389. (b) Gans, P.; Sabatini, A.; Vacca, A. Talanta 1996, 43, 1739.

(14) Convington, A. K.; Paabo, M.; Robinson, R. A.; Bates, R. G. Anal. Chem. 1968, 40, 700 .

(15) Johnson, C. S., Jr. Prog. NMR Spectrosc. 1999, 34, 203.
SPEX Fluorolog 3.22 spectrofluorometer. $\mathrm{HCl}$ and $\mathrm{NaOH}$ were used to adjust the $\mathrm{pH}$ values that were measured on a Meterlab PHM240 Radiometer $\mathrm{pH}$ meter. The linearity of the fluorescence emission vs concentration was checked in the concentration range used $\left(10^{-4}-10^{-6} \mathrm{M}\right)$. The absorbance of the excitation wavelength was maintained lower than 0.15 . When excitation was carried out at wavelengths different from the isosbestic points, a correction for the absorbed light was performed. Fitting of the emission intensity vs [substrate]/[receptor] curves was performed as described in ref 16.

Fluorescence lifetimes were measured with the time-correlated single photon counting technique (TCSPC) as described elsewhere. ${ }^{16}$ The fluorescence decays were analyzed using the method of modulating functions implemented by Striker with automatic correction for the photomultiplier "wavelength shift". ${ }^{17}$

\section{Results and Discussion}

Synthesis. Heteroatomic polyazamacrocycles containing pyridine, pyrazole, furan, and thiophene rings have been obtained by following a two-step synthetic method that consists first of a dipodal $(2+2)$ condensation of $\alpha, \omega$ diamines with an aldehyde followed by hydrogenation of the Schiff base imine bonds. ${ }^{18}$ By means of this synthetic strategy, we have condensed the polyamine $N^{1}, N^{1}$-bis $(2-$ aminoethyl)ethane-1,2-diamine (tren) monofunctionalized with a naphthyl group with 2,6-pyridinedicarbaldehyde in ethanol followed by in situ reduction with sodium borohydride (Scheme 1). The global yield of the reaction is high and allows for disposing of gram quantities of the final product that is handled as its hydrochloride or perchlorate salts. The high yield obtained agrees with those usually reported for dipodal $(2+2)$ condensation of $\alpha, \omega$-diamines with dialdehydes and is much higher than those reported for amines containing $\mathrm{NH}$ groups in the middle of the chain. In such cases, formation of imidazoline rings produces a new isomer which reduces the overall yield of the reaction. ${ }^{18}$ In our case, the tertiary nature the middle nitrogens prevents the formation of such imidazoline isomers and facilitates the formation of the 26-membered macrocyclic ring.

Monofunctionalization of tris(2-aminoethyl)amine (tren) was achieved by reacting the free amine with naphthalene1-carbaldehyde in 3:1 molar ratio followed by treatment with $\mathrm{NaBH}_{4}$. The excess of amine is added to ensure predominant formation of the 1:1 functionalized $\mathbf{L} \mathbf{1}$ compound. The excess of amine is removed along the extraction process.

(16) (a) Albelda, M. T.; Díaz, P.; García-España, E.; Lima, J. C.; Lodeiro, C.; Seixas de Melo, J.; Parola, A. J.; Pina, F.; Soriano, C. Chem. Phys. Lett. 2002, 353, 63. (b) Pina, F.; Lima, J. C.; Lodeiro, C.; Seixas de Melo, J.; Díaz, P.; Albelda, M. T.; García-España, E. J. Phys. Chem. A 2002, 106, 8207. (c) Seixas de Melo, J.; Pina, J.; Pina, F.; Lodeiro, C.; Parola, A. J.; Lima, J. C.; Albelda, M. T.; Clares, M. P.; GarcíaEspaña, E.; Soriano, C. J. Phys. Chem. A 2003, 107, 11307.

(17) Striker, G.; Subranariam, V.; Seidel, C. A. M.; Volkmer, A. J. Phys. Chem. B 1999, 103, 8612.

(18) For related synthesis see for instance: (a) Bailey, N. A.; Eddy, M. M.; Fenton, D. E.; Moss, S.; Mukhopadhyay, A.; Jones, G. J. Chem. Soc., Dalton Trans. 1984, 2281. (b) Chen, D.; Martell, A. E. Tetrahedron 1991, 47, 6895. (c) Dhont, K. I.; Lippens, W.; Herman, G.; Goemine, A. M. Bull. Soc. Chim. Belg. 1992, 101, 1061. (d) Arán, V. J.; Kumar, M.; Molina, J.; Lamarque, L.; Navarro, P.; GarcíaEspaña, E.; Ramírez, J. A.; Luis, S. V.; Escuder, B. J. Org. Chem. 1999, 64, 6135. (e) Menif, R.; Martell, A. E.; Squattrito, P. J.; Clearfield, A. Inorg. Chem. 1990, 29, 4723. (f) Adams, H.; Bailey, N. A.; Fenton, D. E.; Hempstead, P. D.; Westwood, G. P. J. Inclusion Phenom. Mol. Recognit. Chem. 1991, 11, 63. 
Scheme 1
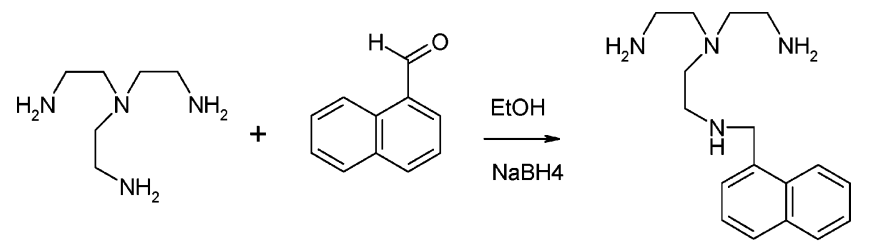

L1
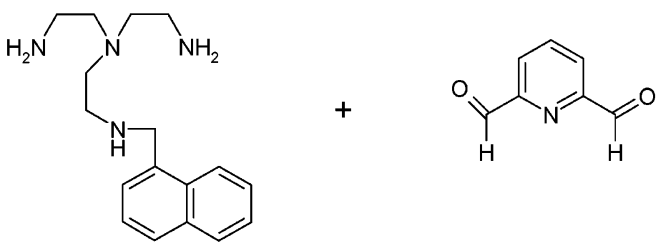

L1
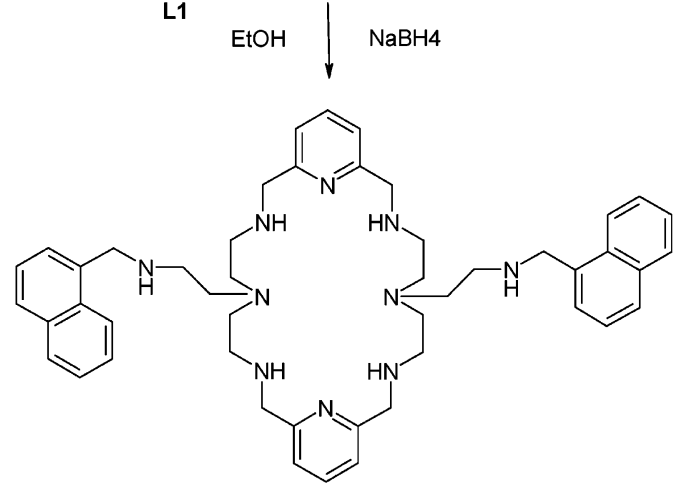

$\mathbf{L}$

Table 1. Protonation Constants of the Macrocycles $\mathbf{L}, \mathbf{L 1}$, and $\mathbf{L 2}$ Determined in $0.15 \mathrm{M} \mathrm{NaCl}$ at $298.1 \mathrm{~K}$

\begin{tabular}{cccc}
\hline \multicolumn{1}{c}{ reacn $^{a}$} & $\mathrm{~L}$ & $\mathrm{~L} 1$ & $\mathrm{~L}^{c}$ \\
\hline $\mathrm{L}+\mathrm{H}=\mathrm{HL}$ & $9.46(3)^{b}$ & $9.72(1)$ & 9.25 \\
$\mathrm{HL}+\mathrm{H}=\mathrm{H}_{2} \mathrm{~L}$ & $8.46(4)$ & $9.10(1)$ & 8.49 \\
$\mathrm{H}_{2} \mathrm{~L}+\mathrm{H}=\mathrm{H}_{3} \mathrm{~L}$ & $7.65(5)$ & $7.45(1)$ & 7.55 \\
$\mathrm{H}_{3} \mathrm{~L}+\mathrm{H}=\mathrm{H}_{4} \mathrm{~L}$ & $7.25(7)$ & & 6.98 \\
$\mathrm{H}_{4} \mathrm{~L}+\mathrm{H}=\mathrm{H}_{5} \mathrm{~L}$ & $6.50(5)$ & & 4.11 \\
$\mathrm{H}_{5} \mathrm{~L}+\mathrm{H}=\mathrm{H}_{6} \mathrm{~L}$ & $6.29(6)$ & & 3.26 \\
$6 \mathrm{H}+\mathrm{L}=\mathrm{H}_{6} \mathrm{~L}$ & 45.61 & & 39.64
\end{tabular}

${ }^{a}$ Charges omitted for clarity. ${ }^{b}$ Values in parentheses are standard deviations in the last significant figure. ${ }^{c}$ Taken from ref 18.

Protonation Constants and Effect of the $\mathrm{pH}$ on the Emissive Behavior. The protonation constants of $\mathbf{L}$ determined in $0.15 \mathrm{M} \mathrm{NaCl}$ at $298.1 \mathrm{~K}$ together with those we have calculated for the tripodal open-chain ligand L1 and those reported in the literature for the pyridinophane macrocycle L2 (see Chart 1) ${ }^{19}$ are presented in Table 1. The distribution diagram together with the results of steady-state fluorescence titration are shown in Figure 1.

Under the experimental conditions used, $\mathbf{L}$ displays six measurable protonation steps with values in the range 9.466.29 logarithmic units. The protonation constants of the four first steps are comparable to those found for the related monocyclic compound $\mathbf{L} 2$ without the dangling arms. The fifth and sixth protonation constants are clearly higher for $\mathbf{L}$ than for $\mathbf{L} \mathbf{2}$ in agreement with the possibility that $\mathbf{L}$ has to dispose the positive charges far away between them in

(19) Lu, Q.; Caroll, R. J.; Reibenspies, J. H.; Martell, A. E.; Clearfield, A. J. Mol. Struct. 1998, 470, 121.
Chart 2

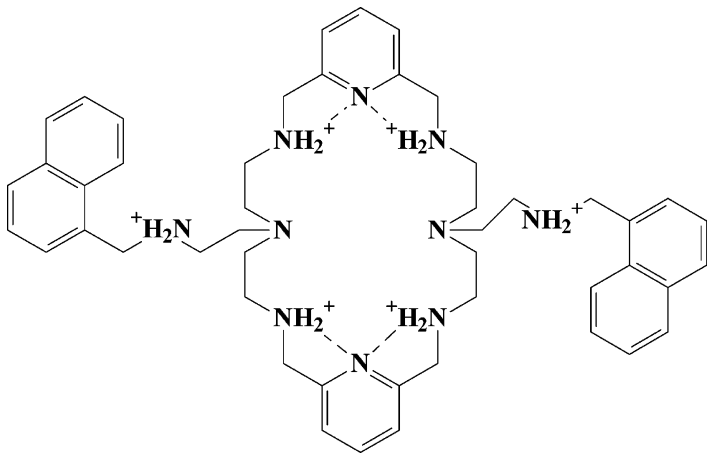

the secondary nitrogen atoms of the macrocycle (See Chart 2 ). In a similar way, the first three constants of $\mathbf{L}$ are close although a little lower than those of L1. The slightly higher constants of the two first protonation steps of $\mathbf{L} \mathbf{1}$ (Table 1) can be ascribed to the presence of two primary amino groups than can stabilize better their charges by hydrogen bonding with the water molecules of the medium.

In agreement with the behavior found for related ligands reported in the literature, ${ }^{19-21}$ the pyridine nitrogen atoms do not seem to experience any net protonation process in the explored $\mathrm{pH}$ range. However, the width of the ${ }^{1} \mathrm{H}$ and ${ }^{13} \mathrm{C}$ signals of protons $\mathrm{Hpy0}$ (for the labeling see Chart 1) suggests that the pyridine nitrogen atoms participate in an intramolecular hydrogen-bonding network. Indeed, at $\mathrm{pH} 6$, the Hpy0 signals very significantly broaden relative to what is found at more acidic $\mathrm{pH}$ values. Also the ${ }^{13} \mathrm{C}$ NMR signals are much broader at this $\mathrm{pH}$.

The fluorescence emission spectra of compound $\mathbf{L}$ reported in Figure 1A shows two bands. The first band centered at $323 \mathrm{~nm}$ is vibrationally resolved and can be easily assigned to the emission of naphthalene (monomer). The second band at $390-400 \mathrm{~nm}$ is much broader and can be assigned to a naphthalene-naphthalene excimer. An analogous spectral pattern has been found for naphthalene derivatives presenting interaction between two chromophores. ${ }^{7,16,23,24}$ Inspection of Figure $1 \mathrm{~B}$ shows that the $\mathrm{H}_{6} \mathrm{~L}^{6+}$ species exhibits both the most intense monomer and most intense excimer emissions. Removal of the first and successive protons produces a strong quenching due to a photoinduced electron transfer from the lone pairs of the deprotonated amine to the excited naph-

(20) Bencini, A.; Bianchi, A.; García-España, E.; Micheloni, M.; Ramírez, J. A. Coord. Chem. Rev. 1999, 88, 97.

(21) (a) Costa, J.; Delgado, R. Inorg. Chem. 1993, 32, 5257. (b) Costa, J.; Delgado, R.; Drew, M. G. B.; Félix, V.; Henriques, R. T.; Warenbourgh, J. C. J. Chem. Soc., Dalton Trans. 1999, 3253.

(22) Seixas de Melo, J.; Albelda, M. T.; Díaz, P.; García-España, E.; Lodeiro, C.; Alves, S.; Lima, J. C.; Pina, F.; Soriano, C. J. Chem. Soc., Perkin Trans. 2 2002, 991.

(23) Albelda, M. T.; García-España, E.; Gil, L.; Lima, J. C.; Lodeiro, C.; Seixas de Melo, J.; Melo, M. J.; Parola, A. J.; Pina, F.; Soriano, C. J. Phys. Chem. B 2003, 107, 6573.

(24) (a) Fabbrizzi, L.; Poggi, A. Chem. Soc. Rev. 1995, 24, 197. (b) Czarnik, A. W. ACS Symp. Ser. 1993, No. 538, 104. (c) Fabbrizzi, L.; Licchelli, M.; Pallavicini, P.; Perotti, A.; Taglietti, A.; Sacchi, D. Chem.-Eur. J. 1996, 2, 75. (d) Akkaya, E. U.; Huston, M. E.; Czarnik, A. W. J. Am. Chem. Soc. 1990, 112, 3590. (e) Fabbrizzi, L.; Licchelli, M.; Pallavicini, P.; Perotti, A.; Sacchi, D. Angew. Chem., Int. Ed. Engl. 1994, 33, 1975. (f) Czarnik, A. W. Acc. Chem. Res. 1994, 27, 302. (g) Valeur, B.; Leray, I. Coord. Chem. Rev. 2000, 205, 3. (h) Valeur, B.; Pouget, J.; Bourson, J. J. Lumin. 1990, 52, 345. 
Clares et al.
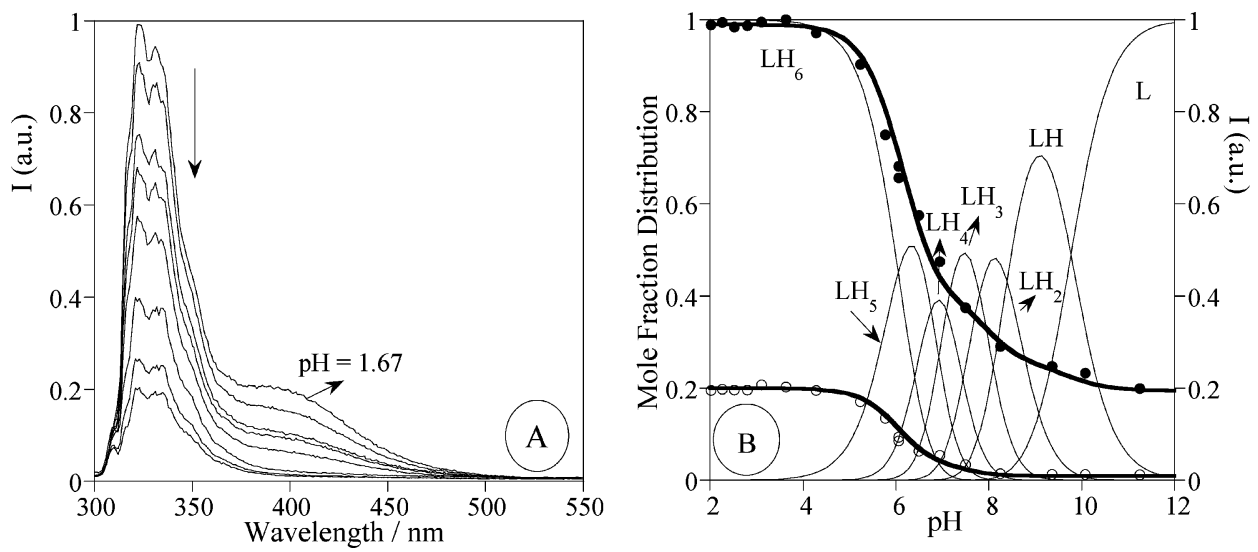

Figure 1. (A) Fluorescence emission spectra of $\mathbf{L}$ recorded at $298.1 \mathrm{~K}$ as function of $\mathrm{pH}$. (pH values: $1.67 ; 5.23 ; 5.77 ; 6.06 ; 7.07 ; 7.85 ; 8.25 ; 11.25$.) (B) Steady-state fluorescence emission titration curves of $\mathbf{L}\left(\lambda_{\text {exc }}=280 \mathrm{~nm}\right)$ for a $7.01 \times 10^{-6} \mathrm{M}$ solution in $0.15 \mathrm{NaCl}$ at $298.1 \mathrm{~K}$ in water: $(\bullet)$ emission followed at $323 \mathrm{~nm}$ (monomer); (O) emission followed at $400 \mathrm{~nm}$ (excimer); (-) molar fraction distributions.

Table 2. Fluorescence Decay Times, Preexponential Factors and $\chi^{2}$ Values Resulting from the Global Analysis of the Decays as a Function of $\mathrm{pH}$ Obtained with Excitation Wavelength of $290 \mathrm{~nm}$ and Emission Wavelengths of 320 and $420 \mathrm{~nm}$

\begin{tabular}{ccccccccc}
\hline $\mathrm{pH}$ & $\lambda_{\mathrm{em}}$ & $\tau_{1} / \mathrm{ns}$ & $\tau_{2} / \mathrm{ns}$ & $\tau_{3} / \mathrm{ns}$ & $a_{i 1}$ & $a_{i 2}$ & $a_{i 3}$ & $\chi^{2}$ \\
\hline \multirow{2}{2}{.1} & 320 & 9.8 & 34 & & 0.917 & 0.083 & & 0.83 \\
& 420 & & & & 0.319 & 0.681 & & 1.04 \\
3.13 & 320 & 10.87 & 35.5 & & 0.926 & 0.074 & & 1.29 \\
& 420 & & & & 0.28 & 0.716 & 1.09 \\
4 & 320 & 10.75 & \multirow{2}{*}{35.5} & & 0.92 & 0.08 & & 1.2 \\
& 420 & & & & 0.135 & 0.861 & & 1.09 \\
5.2 & 320 & 13.8 & \multirow{3}{*}{38.33} & 4.57 & 0.614 & 0.046 & 0.34 & 0.87 \\
& 420 & & & & 0.196 & 0.78 & & 1.01
\end{tabular}

thalene. ${ }^{24}$ This type of quenching has analogously been observed in other polyamine systems bearing naphthalene or anthracene fluorophores. ${ }^{5-7,9,16}$ While the quenched emission from the monomer still remains above $\mathrm{pH}=8$, no excimer emission is observed at those $\mathrm{pH}$ values. In fact, the excimer emission starts to decrease at $\mathrm{pH}=5$, coinciding with the formation of $\mathrm{H}_{5} \mathrm{~L}^{5+}$ and totally disappears at higher $\mathrm{pH}$ values.

To get more information about the excimer formation kinetics we have performed a detailed analysis of the fluorescence decays of $\mathbf{L}$.

In Table 2, the fluorescence decay times and preexponential factors collected at 320 and $420 \mathrm{~nm}$, at different $\mathrm{pH}$ values, are presented. It can be seen that the global analysis of the fluorescence decays leads to biexponential fits until $\mathrm{pH} \cong 4$. From there on, the decays are best fitted with sums of three exponentials.

Note that by direct comparison with Figure 1B, from $\mathrm{pH}$ $=2$ to 4 the only emitting species are the totally protonated $\mathrm{H}_{6} \mathbf{L}^{6+}$ species and an intramolecular excimer. At $\mathrm{pH}=5.2$, the decays become essentially triexponential at the monomer emission wavelength. The independent analysis of the decays at $420 \mathrm{~nm}$ gives rise to biexponential fits with the absence of the shortest component. This new component is totally compatible with the existence, at $\mathrm{pH}$ above 5, of two different protonated species $\left(\mathrm{H}_{6} \mathbf{L}^{6+}\right.$ and $\mathrm{H}_{5} \mathbf{L}^{5+}$ in Figure $\left.1 \mathrm{~B}\right)$ coexisting with the intramolecular excimer. This is also compatible with the fact that $\mathrm{H}_{5} \mathbf{L}^{5+}$ does not form excimer, since the decays at $420 \mathrm{~nm}$ remain unchanged. As the $\mathrm{pH}$ increases, the $\mathrm{H}_{5} \mathbf{L}^{5+}$ species gains weight relative to the $\mathrm{H}_{6} \mathbf{L}^{6+}$ species (see Figure 1B), which leads to an increase in the associated
Table 3. Stability Constants for the Formation of $\mathrm{Cu}^{2+}$ and $\mathrm{Zn}^{2+}$ Complexes of the Macrocycle $\mathbf{L}$ Determined in $0.15 \mathrm{M} \mathrm{NaCl}$ at $298.1 \mathrm{~K}$

\begin{tabular}{clcc}
\hline entry & \multicolumn{1}{c}{ reacn $^{a}$} & $\mathrm{Cu}(\mathrm{II})$ & $\mathrm{Zn}(\mathrm{II})$ \\
\hline 1 & $\mathrm{M}+3 \mathrm{H}+\mathrm{L}=\mathrm{MH}_{3} \mathrm{~L}$ & $41.18(5)^{b}$ & $34.21(2)$ \\
2 & $\mathrm{M}+2 \mathrm{H}+\mathrm{L}=\mathrm{MH}_{2} \mathrm{~L}$ & $36.09(7)$ & $28.48(3)$ \\
3 & $\mathrm{M}+\mathrm{H}+\mathrm{L}=\mathrm{MHL}$ & $28.97(8)$ & $20.92(6)$ \\
4 & $\mathrm{M}+\mathrm{L}=\mathrm{ML}$ & $20.13(9)$ & $11.75(9)$ \\
5 & $2 \mathrm{M}+\mathrm{L}+2 \mathrm{H}=\mathrm{M}_{2} \mathrm{H}_{2} \mathrm{~L}$ & $41.3(1)$ & \\
6 & $2 \mathrm{M}+\mathrm{L}+\mathrm{H}=\mathrm{M}_{2} \mathrm{HL}$ & $37.97(5)$ & \\
7 & $2 \mathrm{M}+\mathrm{L}=\mathrm{M}_{2} \mathrm{~L}$ & $31.06(9)$ & $21.14(4)$ \\
8 & $2 \mathrm{M}+\mathrm{L}+\mathrm{H}_{2} \mathrm{O}=\mathrm{M}_{2} \mathrm{~L}(\mathrm{OH})+\mathrm{H}+\mathrm{H}$ & $21.2(1)$ & $12.39(8)$ \\
9 & $2 \mathrm{M}+\mathrm{L}+2 \mathrm{H}_{2} \mathrm{O}=\mathrm{M}_{2} \mathrm{~L}(\mathrm{OH})_{2}+2 \mathrm{H}$ & $11.47(9)$ & \\
10 & $\mathrm{MH}{ }_{2} \mathrm{~L}+\mathrm{H}=\mathrm{MH}_{3} \mathrm{~L}$ & 5.1 & 5.7 \\
11 & $\mathrm{MHL}+\mathrm{H}=\mathrm{MH}_{2} \mathrm{~L}$ & 7.1 & 7.6 \\
12 & $\mathrm{ML}+\mathrm{H}=\mathrm{MHL}$ & 8.8 & 9.2 \\
13 & $\mathrm{M}_{2} \mathrm{HL}+\mathrm{H}=\mathrm{M}_{2} \mathrm{H}_{2} \mathrm{~L}$ & 3.5 & \\
14 & $\mathrm{M}_{2} \mathrm{~L}+\mathrm{H}=\mathrm{M}_{2} \mathrm{HL}_{12}$ & 6.9 & \\
15 & $\mathrm{M}_{2} \mathrm{~L}+\mathrm{H}{ }_{2} \mathrm{O}=\mathrm{M}_{2} \mathrm{~L}(\mathrm{OH})+\mathrm{H}$ & -9.9 & -8.8 \\
16 & $\mathrm{M}_{2} \mathrm{~L}(\mathrm{OH})+\mathrm{H}_{2} \mathrm{O}=\mathrm{M}_{2} \mathrm{~L}(\mathrm{OH})_{2}+\mathrm{H}$ & -10.0 & \\
17 & $\mathrm{ML} \mathrm{M}=\mathrm{M}_{2} \mathrm{~L}$ & 10.9 & 9.4
\end{tabular}

${ }^{a}$ Charges omitted for clarity. ${ }^{b}$ Values in parentheses are standard deviations in the last significant figure.

preexponential factor of the shortest decay time; see Table 2.

The absence of negative amplitudes associated with the decay times found at $420 \mathrm{~nm}$ can be explained by either a strong contribution of the monomer emission at that wavelength (in comparison with the weak excimer emission) and/ or to the presence of preformed dimers, that cannot be excluded.

NMR DOSY experiments performed at $\mathrm{pH}=6$ (Figure S1) show the presence of at least three different conformers of $\mathbf{L}$ in solution with close diffusion coefficients. The diffusion coefficients obtained together with the dilution experiments performed rule out the possibility of intermolecular aggregation in the concentration range of study. Therefore, the different conformers observed should correspond to intramolecular arrangements with different shape and consequently different hydrodynamic radius.

Interaction with Metal Ions. Table 3 gathers the cumulative and some selected stepwise constants for the interaction of $\mathbf{L}$ with the metal ions $\mathrm{Cu}$ (II) and $\mathrm{Zn}$ (II) determined at $298.1 \mathrm{~K}$ in $0.15 \mathrm{M} \mathrm{NaCl}$ aqueous solutions.

Formation of mono- and dinuclear complexes has been detected in all the studied systems. The mononuclear 

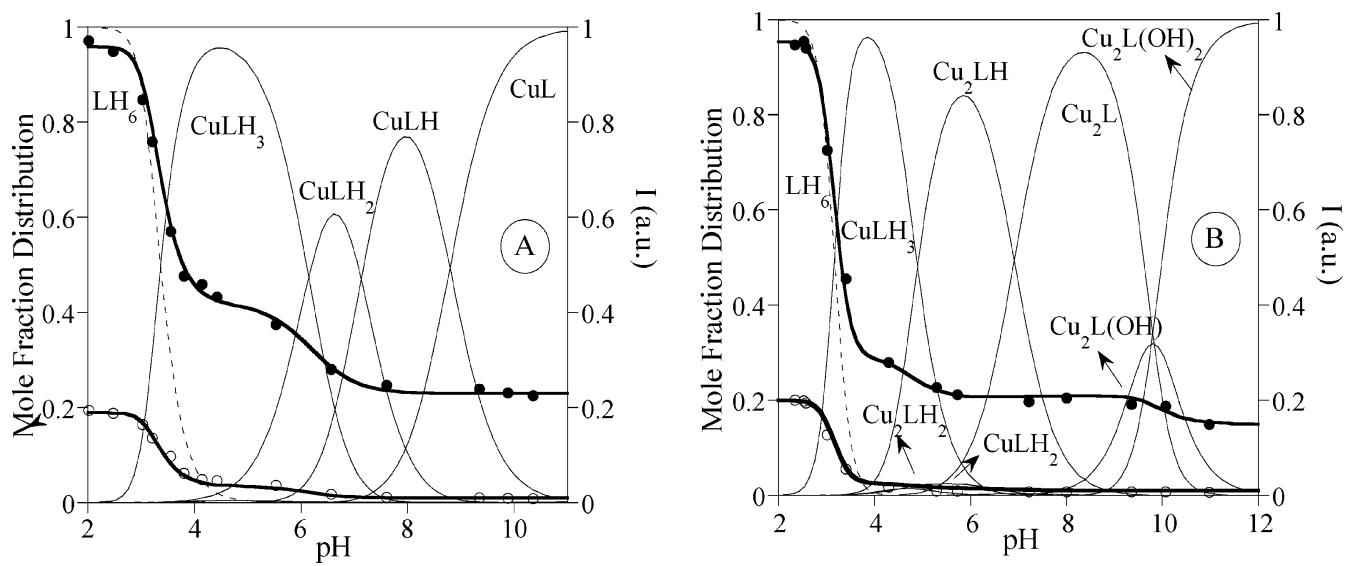

Figure 2. Steady-state fluorescence emission titration curves for the system $\mathrm{Cu}^{2+}-\mathbf{L}\left(\lambda_{\mathrm{exc}}=280 \mathrm{~nm}\right)$ for a $7.01 \times 10^{-6} \mathrm{M}$ of $\mathbf{L}$ (molar ratio $1: 1 \mathbf{L}: \mathrm{M}(\mathrm{A})$ and 1:2 L:M (B)), with $0.15 \mathrm{M} \mathrm{NaCl}$ at $298.1 \mathrm{~K}$ in water: $(\bullet)$ emission followed at $323 \mathrm{~nm}$ (monomer); (O) excimer emission followed at $400 \mathrm{~nm}$; (free ligand dotted lines and metal complex solid lines) molar fraction distributions.

complexes display $\left[\mathrm{M}\left(\mathrm{H}_{3} \mathbf{L}\right)\right]^{5+},\left[\mathrm{M}\left(\mathrm{H}_{2} \mathbf{L}\right)\right]^{4+},[\mathrm{M}(\mathrm{HL}])^{3+}$, and $[\mathrm{ML}]^{2+}$ stoichiometries. The dinuclear $\mathrm{Cu}^{2+}$ complexes present $\left[\mathrm{Cu}_{2}\left(\mathrm{H}_{x} \mathbf{L}\right)\right]^{(4+x)}$ stoichiometries with $x$ values varying from 2 to -2 . For 2:1 M:L molar ratios these species predominate throughout all the $\mathrm{pH}$ range studied (see Figure 2). For the $\mathrm{Zn}^{2+}$ system, only the dinuclear species $\left[\mathrm{M}_{2} \mathbf{L}\right]^{4+}$ and $\left[\mathrm{M}_{2} \mathbf{L}(\mathrm{OH})\right]^{3+}$ are found.

The high values of the protonation constants of the mononuclear complexes (entries 10-12, Table 3) agree with the fact that these protonation processes take place at noncoordinated nitrogen atoms. Indeed, the 10 potential donor atoms existing in the macrocycle exceed the optimal coordination numbers of anyone of these metal ions. The donor atoms can be classified into four categories: (i) the two pyridine nitrogens; (ii) the four secondary amino groups in the polyamine bridges; (iii) the two secondary amino groups of the dangling arms; (iv) the two tertiary central nitrogen atoms of the bridges (see Chart 1 and Scheme 1). Geometrical reasons prevent the simultaneous participation of some of these atoms in the coordination to the same metal ion. For instance, it is unlikely that both pyridine nitrogen atoms can simultaneously get close enough to bind a single metal ion since they lie rather far apart. Molecular models show distances for the separation between the pyridine nitrogens that go over $6.5 \AA$ in all the cases. Moreover, in the crystal structure of the dinuclear $\left[\mathrm{Cu}_{2}(\mathbf{L 2})\right]\left(\mathrm{ClO}_{4}\right)_{4} \cdot 4 \mathrm{DMF}$ complex reported by Martell et al., ${ }^{19}$ the larger axis of the macrocyclic hole was that bisecting the opposite pyridine nitrogen atoms. Therefore, the coordination of the first metal ion should involve one of the pyridine nitrogen atoms that as they do not take part neatly in protonation processes, will have their lone pair always available for the coordination and the amino nitrogen atoms close to it. Such a coordination was also the one observed in each one of the two coordination sites of the solid complex $\left[\mathrm{Cu}_{2}(\mathbf{L} 2)\right]\left(\mathrm{ClO}_{4}\right)_{4} \cdot 4 \mathrm{DMF} .{ }^{19}$ The number of nitrogen atoms involved in the coordination deserves, however, further analysis. In this sense although, as is correctly stated, deriving coordination numbers just from free energy terms can be very misleading, in some instances a careful comparison with appropriate systems can provide good hints at this respect. The reported values for the
Table 4. Stability Constants for the Formation of $\mathrm{Cu}^{2+}$ and $\mathrm{Zn}^{2+}$ Complexes of the Tripodal Ligand $\mathbf{L 1}$ Determined in $0.15 \mathrm{M} \mathrm{NaCl}$ at $298.1 \mathrm{~K}$

\begin{tabular}{clcc}
\hline entry & \multicolumn{1}{c}{ reacn $^{a}$} & $\mathrm{Cu}(\mathrm{II})$ & $\mathrm{Zn}(\mathrm{II})$ \\
\hline 1 & $\mathrm{M}+\mathrm{H}+\mathrm{L}=\mathrm{MHL}$ & $21.25(2)^{b}$ & $17.53(7)$ \\
2 & $\mathrm{M}+\mathrm{L}=\mathrm{ML}$ & $17.43(1)$ & $12.50(1)$ \\
3 & $\mathrm{M}+\mathrm{L}+\mathrm{H}_{2} \mathrm{O}=\mathrm{ML}(\mathrm{OH})+\mathrm{H}$ & $8.49(2)$ & $2.62(2)$ \\
4 & $\mathrm{ML}+\mathrm{H}=\mathrm{MHL}$ & 3.8 & 5.0 \\
5 & $\mathrm{ML}+\mathrm{H}_{2} \mathrm{O}=\mathrm{ML}(\mathrm{OH})+\mathrm{H}$ & -8.9 & -9.9
\end{tabular}

${ }^{a}$ Charges omitted for clarity. ${ }^{b}$ Values in parentheses are standard deviations in the last significant figure.

formation of the $[\mathrm{CuL}]^{2+}$ complex by the $2: 2$ pyridinophane $\mathbf{L} 2$ is $\log K_{\mathrm{ML} / \mathrm{M} \cdot \mathrm{L}}=20.90$, which is very close to the value we have obtained for $\mathbf{L}$ (Table 3, entry 4 ). If we compare with L1 (Table 4), the tripodal synthon used for the preparation of $\mathbf{L}$, the value obtained in this case $\left(\log K_{\mathrm{ML} / \mathrm{M} \cdot \mathrm{L}}\right.$ $=17.42$ ) is lower than for $\mathbf{L} \mathbf{1}$ and for $\mathbf{L} \mathbf{2}$. Nevertheless, it has to be emphasized that these ligands have donor atoms with different characteristics. $\mathbf{L} 1$ has two primary nitrogen donors that display $\sigma$-donating abilities different from those of the secondary nitrogens in the bridges of $\mathbf{L}$ or $\mathbf{L} 2$. Comparisons with other related tetraamines or pentaamines also point in the same direction. ${ }^{21,26,27}$ Thereby, all these data suggest a coordination number of 4 as likely for the mononuclear complexes of $\mathbf{L}$, although the participation of another nitrogen occupying a distorted axial position cannot be ruled out.

In this respect, one point of interest regards whether the atoms in the dangling arms are coordinated to the metal ion or not. To have some more light about this point, we have recorded the $\mathrm{UV}$-vis spectra at $\mathrm{pH}$ values corresponding with the protonated $\left[\mathrm{Cu}\left(\mathrm{H}_{x} \mathbf{L}\right)\right]^{(2+x)}$ and neutral $[\mathrm{Cu} \mathbf{L}]^{2+}$ species. The spectra do not experience significant variations for the different species and suggest that there are not important changes in the coordination environment although they are rather uninformative. The observed changes in the UV region of the spectra are also meaningless.

(25) de Silva, A. P.; Gunaratne, H. Q. N.; Coy, C. P. M. Chem. Commun 1996, 2399.

(26) Rothermel, G. L., Jr.; Miao, L.; Hill, A. L.; Jackels, S. C. Inorg. Chem. 1992, 31, 4854.

(27) Basallote, M. G.; Durán, J.; Fernández-Trujillo, J.; Máñez, M. A Quirós, M.; Salas, J. M. Polyhedron. 2001, 20, 297. 


\section{Clares et al.}

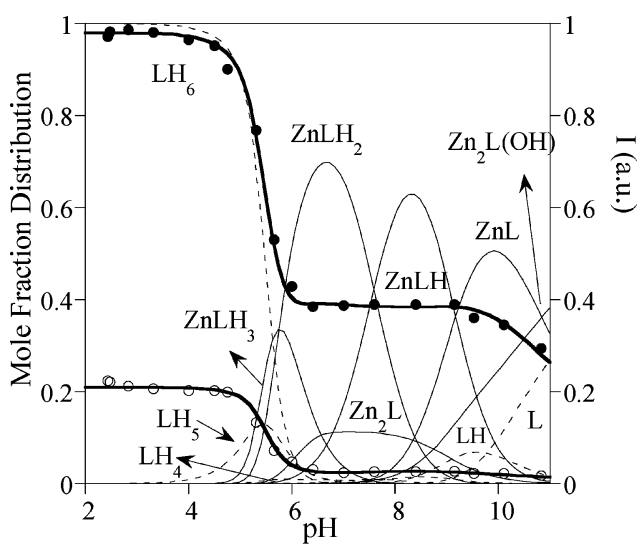

A

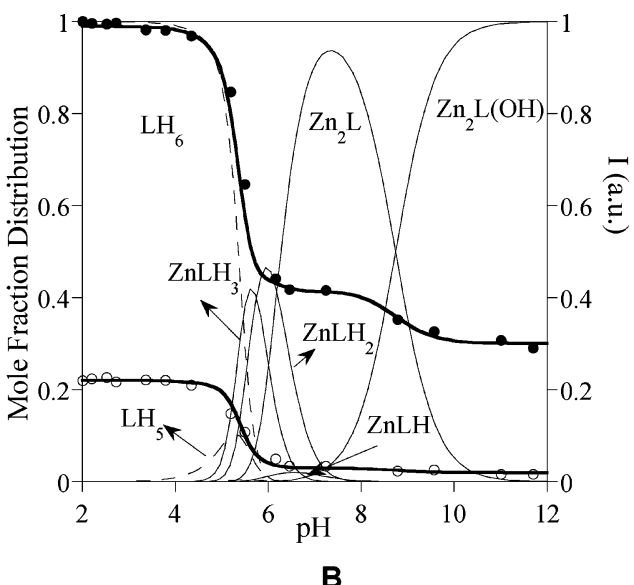

Figure 3. Steady-state fluorescence emission titration curves for the system $\mathrm{Zn}^{2+}-\mathrm{L}\left(\lambda_{\mathrm{exc}}=280 \mathrm{~nm}\right.$ ) for a $1.00 \times 10^{-5} \mathrm{M}$ of $\mathbf{L}$ (molar ratio $1: 1 \mathbf{L}: \mathrm{M}(\mathrm{A})$ and 1:2 L:M (B)), with $0.15 \mathrm{M} \mathrm{NaCl}$ at $298.1 \mathrm{~K}$ in water: (-) emission followed at $323 \mathrm{~nm}$ (monomer); (O) excimer emission followed at $400 \mathrm{~nm}$; (free ligand dotted lines and metal complex solid lines) molar fraction distributions.

With respect to the formation of dinuclear complexes, Figure $2 \mathrm{~B}$ shows that such species are predominant above $\mathrm{pH}=4$, where $\left[\mathrm{Cu}\left(\mathrm{H}_{2} \mathbf{L}\right)\right]^{5+}$ starts to prevail in solution. It is interesting to emphasize that the entry of the second metal ion is characterized by a much lower stability constant than the binding of the first metal ion (entries 4 and 17 in Table $3, \log K_{\mathrm{CuL} / \mathrm{Cu} \cdot \mathbf{L}}=20.13(9)$ and $\log K_{\mathrm{Cu}_{2} \mathrm{~L} / \mathrm{CuL} \cdot \mathrm{Cu}}=10.9$, respectively). This large reduction in stability has to be related to energy consumption due to macrocycle reorganization associated with the binding of the second metal ion. $\mathrm{Cu}_{2} \mathbf{L}^{4+}$ experiences two hydroxylation steps which have very similar and rather high $\mathrm{p} K_{\mathrm{a}}$ values $\left(\log K_{\mathrm{Cu}_{2} \mathrm{~L} / \mathrm{Cu}_{2} \mathrm{~L}(\mathrm{OH}) \cdot \mathrm{H}}=-9.9\right.$ and $\log K_{\mathrm{Cu}_{2} \mathbf{L}(\mathrm{OH}) / \mathrm{Cu}_{2} \mathbf{L}(\mathrm{OH})_{2} \cdot \mathrm{H}}=-10.0$, respectively, entries 15 and 16 in Table 3) pointing out that they occur independently, namely, each in one of the two coordination sites, and that the hydroxo groups do not behave as bridging ligands.

The analysis of the stability data for the mononuclear complexes formed in the system $\mathrm{Zn}^{2+}-\mathbf{L}$ leads to similar conclusions as those of the $\mathrm{Cu}^{2+}-\mathrm{L}$ system. The value of the stability constant for the formation of the $[\mathrm{ZnL}]^{2+}$ species is of the same order of magnitude as those available for other tetraamines such as 1,4,7,10-tetraazadeacaamine (trien) (log $\left.K_{\mathrm{ML} / \mathrm{M} \cdot \mathrm{L}}=12.0\right)$ and higher than those generally reported for triamines such as $1,4,7$-triazaheptane $\left(\log K_{\mathrm{ML} / \mathrm{M} \cdot \mathrm{L}}=\right.$ 8.8). ${ }^{28}$ However, the obtained constant is clearly lower than that reported for the tripodal tetraamine tris(2-aminoethyl)amine (tren) $\left(\log K_{\mathrm{ML} / \mathrm{M} \cdot \mathrm{L}}=14.5\right)$ or than the one we have obtained for L1, which also displays tripodal characteristics $\left(\log K_{\mathrm{ML} / \mathrm{M} \cdot \mathrm{L}}=12.50\right.$, Table 4$)$. The topology of the latter ligands favors a tetrahedral coordination geometry, in which the $\mathrm{Zn}^{2+}$ feels at ease due to the absence of ligand field stabilization of this metal ion. Therefore, although in the case of $\mathrm{Zn}^{2+}$ the differences in the constants are not so relevant due to the full subshell of this metal ion, 4 seems to be a likely coordination number for the mononuclear complexes. The protonation constants of $[\mathrm{ZnL}]^{2+}$ shown in Table 3 (entries 10-12) indicate that these processes take place in noncoordinated nitrogen atoms.

(28) Martell, A. E.; Smith, R. M.; Moteikaitis, R. J. NIST Critical Stability Constants of Metal Complexes Database NIST Standard Reference Database, version 4; NIST: Washington, DC, 1997.
With respect to the binding of a second $\mathrm{Zn}^{2+}$ ion to give dinuclear complexes, the first point to be noticed is that, in this case, the reduction in the constant is much less sharp than in the case of $\mathrm{Cu}^{2+}$ (entries 4 and 17 in Table $3, \log K_{\mathrm{ZnL} / \mathrm{Zn} \cdot \mathbf{L}}=11.75(9)$ and $\log K_{\mathrm{Zn} \mathrm{n}_{2} \mathrm{~L} / \mathrm{ZnL} \cdot \mathrm{Zn}}=$ 9.4, respectively). A second point of interest is the formation of a dinuclear monohydroxo complex $\left(\mathrm{p} K_{\mathrm{a}}=-8.8\right.$, entry 15 ) that is predominant in solution above $\mathrm{pH} 9$ (Figure 3).

A final point of interest regards whether the nitrogen atoms in the bridge are involved, or not, in the coordination to the metal ion. Although the ${ }^{1} \mathrm{H}$ NMR spectra give rise to very broad signals denoting a fluxional behavior or/and to the presence of different conformations, a careful analysis of the ${ }^{1} \mathrm{H}-{ }^{1} \mathrm{H}$ COSY experiments gives some information at this respect. Indeed ${ }^{1} \mathrm{H}-{ }^{1} \mathrm{H}$ correlation experiments performed for the free ligand in the region 4.00-5.00 ppm do not show any cross-peaks since either benzylic protons py0 or N0 (for the labeling, see Chart 1), which are the ones resonating at this frequencies, are magnetically equivalent. Addition of $\mathrm{Zn}^{2+}$ either in 1:1 or 2:1 molar ratio produces the loss of the magnetic equivalence of these methylene protons, and thereby cross-peaks are observed in this region. This observation indicates that the arms are somewhat blocked by the presence of the metal ions suggesting the involvement of the nitrogens in the arms in the coordination. However, the large number of peaks that appear supports again the existence of different conformations for the complexes including those in which the naphthyl nitrogen would not be involved in the coordination.

Steady-State Fluorescence Measurements. Figures 2A,B and $3 \mathrm{~A}, \mathrm{~B}$ collect the fluorescence emission titration curves of $\mathbf{L}$ with $\mathrm{Cu}^{2+}$ and $\mathrm{Zn}^{2+}$ superimposed with the molar fraction distribution curves obtained by potentiometry (Figures 2A and 3A, molar ratio M:L 1:1; Figures $2 \mathrm{~B}$ and $3 \mathrm{~B}$, molar ratio $2: 1$ ).

For the two metal ions, as above-mentioned, the absorption spectra of the complexes are very similar to those of the free ligand, consisting of a typical naphthalene band with maximum values at 262,271, and $280 \mathrm{~nm}$, and are slightly dependent on $\mathrm{pH}$. 


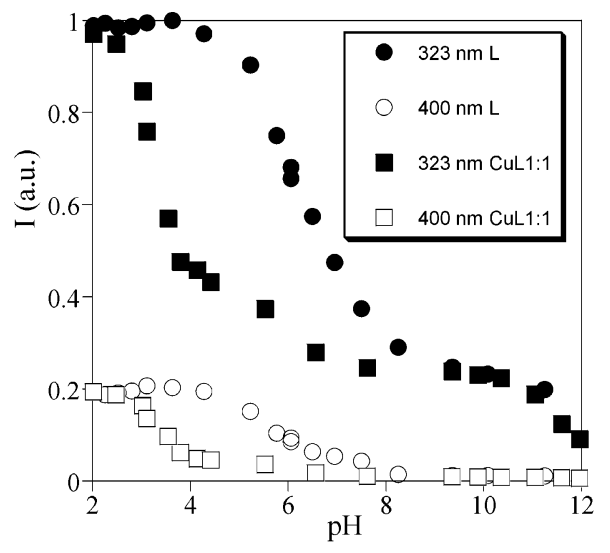

A

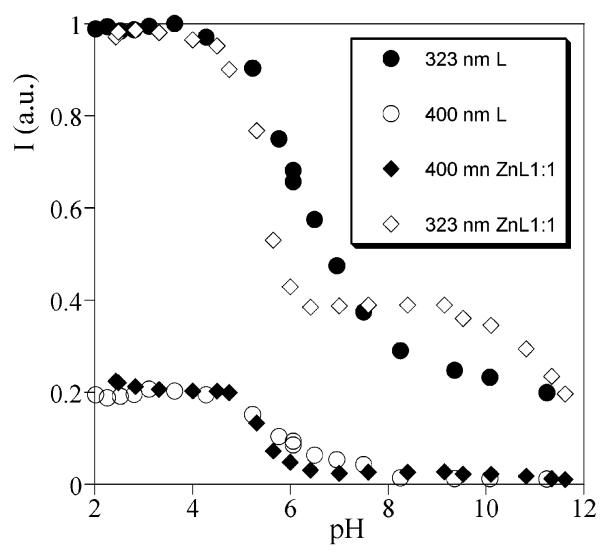

B

Figure 4. Fluorescence emission titration of $\mathbf{L}$ and in the presence of $\mathrm{Cu}(\mathrm{II})$ (A) and $\mathrm{Zn}$ (II) (B) in molar ratio 1:1 M:L.

Concerning the $\mathrm{Cu}^{2+}$ complexes, a strong CHEQ effect (chelation enhancement of the quenching $)^{29}$ can be observed in the $\mathrm{pH}$ range 3.0-5.5, in which the first complex species $\left[\mathrm{Cu}\left(\mathrm{H}_{3} \mathbf{L}\right)\right]^{5+}$ is formed.

In the titrations performed at $\mathrm{M}: \mathrm{L}$ ratios 1:1, a partial quenching effect is observed for all species at neutral and alkaline $\mathrm{pH}$ values $\left[\mathrm{Cu}\left(\mathrm{H}_{3} \mathbf{L}\right)\right]^{3+},\left[\mathrm{Cu}\left(\mathrm{H}_{2} \mathbf{L}\right)\right]^{2+},[\mathrm{Cu}(\mathrm{HL})]^{+}$, and $[\mathrm{CuL}]^{2+}$. In the titration carried out at 2:1 M:L molar ratio, a stronger quenching is observed for all the species presented in solution, namely $\left[\mathrm{Cu}_{2}\left(\mathrm{H}_{2} \mathbf{L}\right)\right]^{4+},\left[\mathrm{Cu}_{2}(\mathrm{HL})\right]^{3+}$, $\left[\mathrm{Cu}_{2} \mathbf{L}\right]$, and the hydroxylated complexes $\left[\mathrm{Cu}_{2} \mathbf{L}(\mathrm{OH})\right]^{+}$and $\left[\mathrm{Cu}_{2} \mathbf{L}(\mathrm{OH})_{2}\right]^{+}$. This quenching of the fluorescence emission upon $\mathrm{Cu}^{2+}$ complexation is commonly observed in polyamine ligands containing aromatic fluorophores and is attributed to an energy transfer quenching of the $\pi^{*}$ emissive state through low-lying metal-centered states. ${ }^{5}$

In contrast with $\mathrm{Cu}^{2+}$, the $\mathrm{Zn}^{2+}$ complexes of polyamine ligands are in generally emissive species leading to a CHEF effect (chelation enhancement of the fluorescence emission). ${ }^{5 c, 30}$ Comparison of the fluorescence emission titration curves, reported in Figures1 and 4, shows that in this case a very modest CHEF effect is manifested for the monomer emission in the $\mathrm{pH}$ range $8-11$. Concerning the excimer emission, coordination of $\mathbf{L}$ to $\mathrm{Zn}^{2+}$ breaks the interaction between the cromophoric units, leading to the disappearance of the excimer above $\mathrm{pH}=6$, Figure 3 .

The naphthylic nitrogens, the closest to the fluorophoric units, are the most important in the electron-transfer quenching process that allows signaling the presence of protons and metal cations in polyamine systems. ${ }^{16}$ The stronger the involvement of these nitrogens in protonation and/or complexation, the stronger is the luminescence of the ligand. That is the reason complexation with $\mathrm{Zn}^{2+}$ is expected to produce a CHEF effect (Figure 3). On the other hand, protonated pyridine is known to quench anthracene fluorescence by a photoinduced electron-transfer mechanism ${ }^{25}$ from the excited

(29) Alves, S.; Pina, F.; Albelda, M. T.; García-España, E.; Soriano, C.; Luis, S. V. Eur. J. Inorg. Chem. 2001, 2, 405.

(30) (a) Valeur, B. Molecular Fluorescence. Principles and Applications; Wiley-VCH: Weinheim, Germany, 2002. (b) Bernardo, M. A.; Pina, F.; García-España, E.; LaTorre, J.; Luis, S. V.; Llinares, J. M.; Ramírez, J. A.; Soriano, C. Inorg. Chem. 1998, 37, 3935. anthracene to the pyridinium. Participation of the pyridine lone pair in $\mathrm{Zn}^{2+}$ complexation is expected to produce the same effect in the naphthalene emission. As a consequence, the expected CHEF arising from the involvement of the secondary amine lone pairs in metal ion complexation is compensated by CHEQ due to the complexed pyridine moiety.

For comparison purposes, steady-state fluorescence emission titrations were carried out in the absence and in the presence of $\mathrm{Cu}^{2+}$ and $\mathrm{Zn}^{2+}$ for the more flexible tripodal ligand $\mathbf{L 1}$, in which all four nitrogen atoms are involved in the coordination, Figures 5 and 6 . In the system $\mathrm{Cu}^{2+}-\mathbf{L} \mathbf{1}$, $\mathrm{Cu}^{2+}$ coordination produces a partial quenching of the emission in the $\mathrm{pH}$ range where the species $[\mathrm{CuHL1}]^{3+}$ and $[\mathrm{CuL1}]^{2+}$ exist. Formation of the monohydroxylated species $[\mathrm{CuL1}(\mathrm{OH})]^{+}$induces complete quenching of the fluorescence. In the case of $\mathrm{Zn}^{2+}$, a large CHEF effect is observed above $\mathrm{pH}=6$, Figure 6 , that decreases upon hydroxylation of $[\mathrm{ZnL1}]^{2+}$. While the CHEQ effect of $\mathrm{Cu}^{2+}$ is strong in both systems, the CHEF effect of $\mathrm{Zn}^{2+}$ with $\mathbf{L 1}$ is much stronger than with $\mathbf{L}$, once again confirming the quenching of naphthalene emission by the complexed pyridine moiety.

Fluorescence decays in the presence of metal ions were also measured. The fits are multiexponential, and the decay times and amplitudes are given as Supporting Information.

\section{Conclusions}

A novel bibrachial lariat aza-crown containing pyridine spacers and 2-((naphthylmethyl)amino)ethyl appendages has been prepared in good yield and its protonation behavior and $\mathrm{Cu}^{2+}$ and $\mathrm{Zn}^{2+}$ coordination chemistry studied by a variety of techniques.

The molecule presents different conformers as a function of $\mathrm{pH}$. These ground-state conformers affect remarkably the emissive properties of the ligand. Steady-state fluorescence measurements show emissions due to the monomer and to excimer formed between the two naphthalene fragments of the macrocycle. The time-resolved fluorescence data and DOSY experiments show that a significant percentage of excimer is preformed as ground-state dimers.

Complexation of $\mathbf{L}$ with $\mathrm{Cu}^{2+}$ and $\mathrm{Zn}^{2+}$ shows the formation of mono- and dinuclear complexes in which the 
Clares et al.
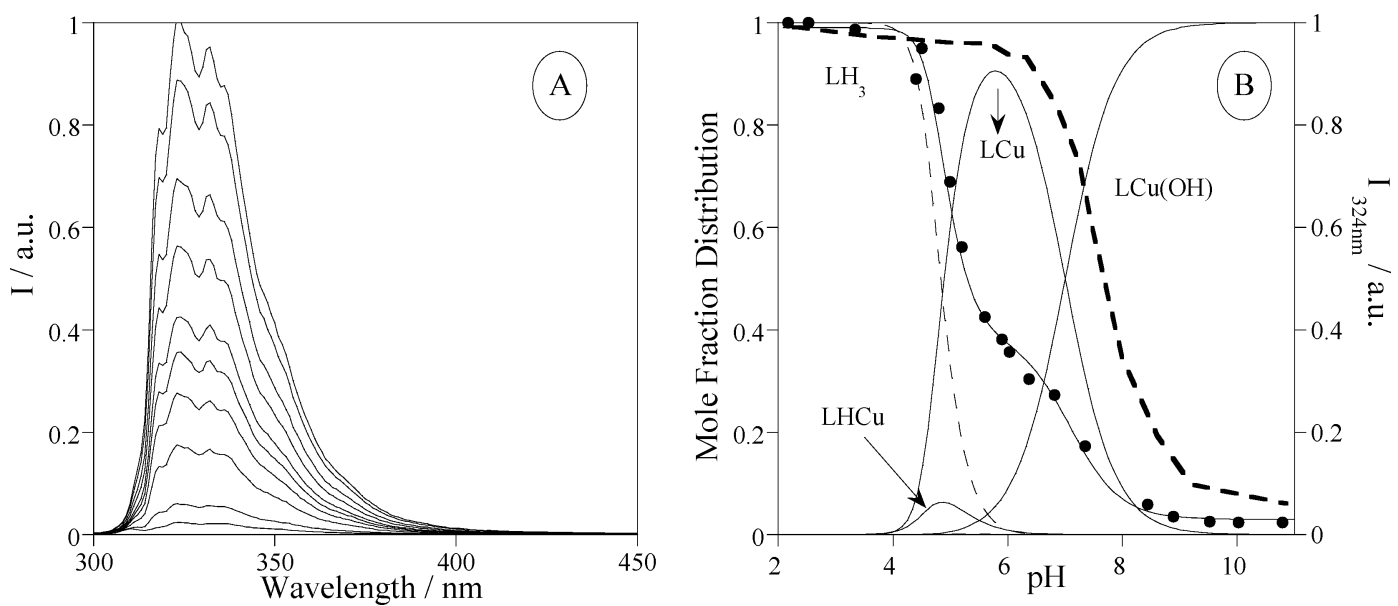

Figure 5. (A) Fluorescence emission spectra at excitation wavelength of $280 \mathrm{~nm}$ of the system $\mathrm{Cu}^{2+}-\mathbf{L 1}$ at $298.1 \mathrm{~K} .\left[\mathrm{Cu}^{2+}\right]=[\mathbf{L 1}]=3.23 \times 10^{-5} \mathrm{M}^{2}$ in the presence of $0.15 \mathrm{M} \mathrm{NaCl}$ and at $\mathrm{pH}=2.00,4.32,5.15,5.40,5.77,6.03,6.81,7.60,8.44$, and 10.80. (B) Fluorescence emission spectra of the system $\mathrm{Cu}^{2+}-\mathbf{L 1}$ at $298.1 \mathrm{~K}\left(\lambda_{\mathrm{exc}}=280 \mathrm{~nm}, \lambda_{\mathrm{em}}=324 \mathrm{~nm}(\bullet),\left[\mathrm{Cu}^{2+}\right]=[\mathbf{L 1}]=3.23 \times 10^{-5} \mathrm{M},[\mathrm{NaCl}]=0.15 \mathrm{M}\right)$, superimposed on the respective mole fraction distribution of the different species present in solution. Protonated curves are indicated by dashed lines, and complexed curves, by solid lines. In (B) is included the emission of the free ligand (black dotted bold lines).
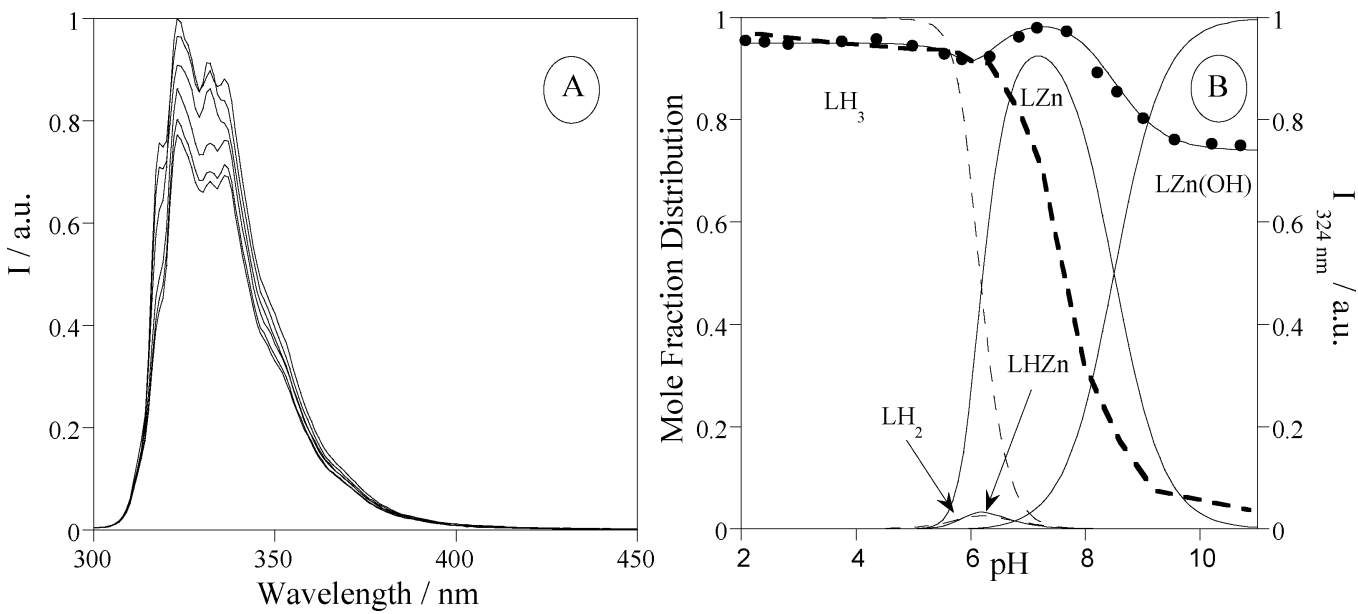

Figure 6. (A) Fluorescence emission spectra at excitation wavelength of $280 \mathrm{~nm}$ of the system $\mathrm{Zn}^{2+}-\mathbf{L 1}$ at $298.1 \mathrm{~K}$ in the presence of $0.15 \mathrm{M} \mathrm{NaCl}$ and $\mathrm{pH}=2.07,5.84,7.15,8.20,9.00$, and 10.70 . (B) Fluorescence emission spectra of the system $\mathrm{Zn}^{2+}-\mathbf{L} 1$ at $298.1 \mathrm{~K}\left(\lambda_{\mathrm{exc}}=280 \mathrm{~nm}, \lambda_{\mathrm{em}}=324 \mathrm{~nm}(\bullet)\right.$, $\left.\left[\mathrm{Zn}^{2+}\right]=[\mathbf{L 1}]=3.23 \times 10^{-5} \mathrm{M},[\mathrm{NaCl}]=0.15 \mathrm{M}\right)$, superimposed on the respective mole fraction distribution of the different species present in solution. Protonated curves are indicated by dashed lines, and complexed curves, by solid lines. In (B) is included the emission of the free ligand (black dotted bold lines).

nitrogen atoms in the pendant arms do not provide a strong contribution to the overall stability. $\mathrm{Cu}^{2+}$ complexation gives rise to a CHEQ effect while $\mathrm{Zn}^{2+}$ originates a slight $\mathrm{CHEF}$ effect. The acid-base, coordination capabilities, and emissive behavior of $\mathbf{L}$ were compared with those presented by its synthetic precursor L1. The differences in fluorescence properties evidenced by their $\mathrm{Zn}^{2+}$ complexes support the existence of an electron-transfer quenching mechanism from excited naphthalene to complexed pyridine.

Acknowledgment. Financial support from the Generalitat Valenciana AVCYT (Spain), projects GV04B225 and GRUPOS03/198 Acciones Integradas Hispano-Portuguesas, project 32442/99 PRAXIS/QUI/10137/98 (Portugal), FEDER (Portugal), and European Community's Human Potential Program under contract HPRN-CT-2000-00029 (Molecular
Level Devices and Machines) is gratefully acknowledged. C.L. acknowledges a postdoctoral grant from contract HPRNCT-2000-00029. R.A. acknowledges the MECD for a Ph.D. grant (AP2002-1382).

Supporting Information Available: Table S1, listing fluorescence decay times $\left(\tau_{i}\right)$ and preexponential factors $\left(A_{i j}\right)$ as a function of $\mathrm{pH}$ for the metal:ligand $\left(\mathrm{Zn}: \mathrm{L}, \mathrm{Zn}_{2}: \mathrm{L}\right.$, and $\left.\mathrm{Cu}: \mathrm{L}\right)$ complexes obtained with excitation wavelength of $285 \mathrm{~nm}$ and emission wavelengths of 320 and $420 \mathrm{~nm}$, text discussing the results from Table 1, Figure S1, showing a DOSY experiment for L recorded at $\mathrm{pD}=6.4$, and a description of the experimental procedure of the DOSY measurements. This material is available free of charge via the Internet at http://pubs.acs.org.

IC049694T 